\title{
Bureaucratic Reform in Public Service: A Case Study on the One Stop-Integrated Service
}

\author{
Yusriadi ${ }^{1}$ \\ Haedar Akib² \\ Andi lhsan ${ }^{3}$ \\ ${ }^{1}$ Doctoral Degree Program, State University of Makassar \\ ${ }^{2}$ Public Administration Department, State University of Makassar \\ 3Physical Education Department, State University of Makassar
}

Doi:10.5901/mjss.2017.v8n2p253

\begin{abstract}
This study aimed at identifying the implementation of bureaucratic reforms and trying to offer some solutions for improvement of administrative services licensing. This study applied qualitative approach using a case study design. Techniques of data collection used three kinds of instrument, namely: observation, in-depth interviews, and office documentation. The data were analyzed through the stages of data reduction, data presentation, and conclusions and verification. The results found that the implementation of the bureaucratic reform of administration service licensing on the Institutional aspects in Bone regency have shaped the One Stop-Integrated Service; on the aspects of human resources found that the qualification of existing employees were not appropriate to the needs of the organization which lack of employees' disciplines and responsibilities; on the aspects of systems and procedures indicated that the licensing generally resolved exceeds the specified time of period as well as discrimination and inconsistencies. Through this study, the researcher made verification in some of the concepts and theories in the form of formalism as one of the characteristics of prismatic society proposed by Fred W. Riggs in those phenomena which called "Heresy Regulation".
\end{abstract}

Keywords: Bureaucratic Reform, Decentralization, Public Service, Pathology Bureaucracy

\section{Introduction}

Studies on the bureaucracy were extremely complex because it deals with various aspects, such as institutional, human resources, systems and procedures are developed and implemented by the bureaucracy, as well as aspects of bureaucratic reform. In that context, the country established an administration system which aims to serve the interests of the community known as bureaucracy.

Public services aimed at the welfare of the people so that the public bureaucracy should contribute greatly to the ministry because all state administration cannot be separated from the context of public service and public affairs. Similarly, public goods and services should be managed efficiently and effectively. So the consequences of such management are the responsibility of the bureaucracy. In addition, the strategic role of government is to sustain and support the public bureaucracy in carrying out their duties and functions.

The huge challenge faced by the bureaucracy is how they are able to carry out the duties and responsibilities efficiently and effectively because during this time, people always view the bureaucracy as a service process is very complicated, rich of structure and poor of function, a lot of corruption, collusion, and nepotism, as well as the poor of basic operational standards. Those problems of bureaucracy have become a very significant obstacle in the framework of the embodiment of bureaucratic reform. Those factors also have turned the Indonesian bureaucracy goal from the good governance.

There are different types or forms of obstruction of bureaucratic reform that has well known and felt by the Indonesian public, among other, the cumbersome of service procedures, inefficient or require a long time process, the huge and additional costs, impolite in providing services, the existence of collusion, corruption and nepotism, and so forth. Those obstacles faced by bureaucratic reform led to the performance of the bureaucracy have not yet to show any significant change. Those facts give an indication that bureaucratic reforms need to be implemented in the context of changes in accordance with the demands and the development of society. As revealed by Hughes that the reason for the reform are: (1) realizing a new approach to carry out a public service function better towards managerial rather than the 
administrative, (2) as a response to the scale of the handling and scope of duty of the government, (3) changes in theory and economic issues, and (4) changes in the role of the private sector in public service implementation (Dwiyanto, 2012).

One point of public services within the scope of Bone Regency is also quite crucial, namely, administrative services licensing. The interesting phenomena that justify their public service problem are the tendency of society who need the service, preferring to use intermediaries rather than directly to the care of the service in accordance with the procedures and applicable regulations. The phenomena prove that the various types of public service and administrative service licensing are very interesting to study. Moreover, the research setting in administration service bureaucracy licensing, who in general, many researchers are more likely to examine this object from a legal perspective, without regard to the administrative dimension as a system that hampers the implementation of bureaucratic reform. These dimensions which will be the focus of research and some aspects included; institutional, human resources, and systems and procedures, so that the research results expected to be more holistic and substantive. Based on this background, therefore this research will have a novelty value.

\subsection{Theoretical review}

Fried W. Riggs in his research in developing countries have found the bureaucratic model which called the "Sala model" or commonly called the "prismatic model". The word 'Sala' is derived from the Spanish word means the government offices in the countries of Latin America. In general, the meaning of 'Sala' is "room". In the French language, it is synonymous with "Salle" which is basically still in the same family of languages. In everyday usage, the word 'Sala' implies a private room in a religious home, public meeting rooms, and even also primarily connotes to the government office (Riggs, 1988).

Sumartono, et al (2012) stated that the essence of public service refers to incentives as a determining factor for the bureaucracy subordinates (street level bureaucracy) in the creation of service satisfaction to customers. While Wijaya and Dana (2014) explained that bureaucratic reforms regarding institutional improvement, human resources, as well as the system of procedures which carried out as well as possible. It is similar to what stated by Dugget (in Rewansyah, 2012) that the reform of the bureaucracy is a continuous process undertaken to redesign the bureaucracy within the government.

The definitions above are different from Boniface .S. Mgonja and Charles Tundui (2012) argue that bureaucratic reform is a matter of regional government institutions toward the program of local Good Governance to improve socioeconomic conditions of the country. It requires the anti-corruption strategy and the reform of local government where there are worse institutions in the system of government, so the reform is expected to improve the good governance through local institutional reform and autonomy. Beside, Rosemary, et al (2012) suggested that managing the public sector needs to adopt a new style of management. The strategies for the civil servants surveillance system that services are oriented on the output and outcome of the socio-economic development of the nation. The civil servants should be regulated in order to be pioneer or agent in the process of change and managing change.

Carl Dahlstrom, et al (2011) focused on the research results of the bureaucracy dimensional structure and behavioral aspects of public administration are bureaucratic structures labeled dimension of professionalism and focus on the quality of the state apparatus so that the pattern of recruitment and career in the bureaucratic system needs more attention. Meanwhile, Muhammad Azizuddin (2011) states that the ruling party over reforms directed at building hegemony so the bureaucracy being split, of course, it will be the pros and cons in the attitude of the government. So the recommendation to require political will (including the intent and authority) from the government to critically assess the ability, the level of cooperation obtained from the civil servant offender and relevance and appropriateness of intervention of international donors. While Sorin and Sandor (2012) argues that public service is still problematic where public bureaucracy reform did not install the ICT and did not have a significant relationship with the e-government, thus requiring staff skills in collaboration and design work; organizational change of hierarchical structure that is more horizontal to the network or even a virtual organization, and the entire government.

Based on some previous studies that have been conducted relating to the reform of bureaucracy show there were still inequality study in which they had only seen in terms of internal bureaucracy to the exclusion of the external aspects of the bureaucracy or people who use the services that influence the reform of the bureaucracy, therefore, this research becomes extremely important to carry out by looking at some aspects of society service users in the implementation of bureaucratic reform. 


\section{Method}

This study employed qualitative approach using a case study design to observe the phenomena holistically and naturalistically. The data gained from this study have been analyzed using the analytical approach of the interactive model by Miles and Huberman (2015).

\subsection{Subject and instrument of the research}

The main data of this study gained from the interviews with employees who were directly involved in the public administration services and also with the stakeholders of Integrated Licensing Service Agency (BP2T) in Bone District, as well as the service users of public services provided by BP2T of Bone regency. For the purposes of the triangulation, the data also obtained through observation. While for some additional data gained from the office document.

\subsection{Validity of data}

To ensure the degree of data confidence in findings, the researcher has strived to maintain the validity of the data collected. The technique to maintain the validity of data, among others; a) persistence of observations, b) triangulation, c) carrying out peers checks through discussion, d) the presentation of a detailed description, and d) perform auditing.

\subsection{Technique of data analysis}

The technique of data analysis used the interactive model developed by Miles and Huberman (2015). This analysis consisted of three basic components, namely; data reduction, data presentation, and conclusion or verification in which the mechanism takes place interactively. The analysis processes started from the data collection at the beginning and continued until the end of the study.

\section{Results}

\subsection{Institutional Aspects}

The one stop integrated service (PTSP) is a set of reforms to the public service, particularly in terms of licensing services which are regulated by the Ministry of Home Affairs Number 24 Year 2006 regarding the system of licensing services under the authority of regional, provincial and district/city. This regulation was the legal basis of PTSP's implementation in all provinces and districts/cities throughout Indonesia. Further institutional policy on PTSP was specifically stipulated in Minister of Home Affairs regulation Number 20 Year 2008 on the Institutional of PTSP in those areas. In Bone regency, local regulations about PTSP are in Regional Regulation No. 4 of 2008 on the establishment of the organization of regional technical institute of Bone regency.

The local regulation stipulates that the permit applications is done through the Integrated Licensing Service Agency (BP2T) as well as the signing of the consent native delegated to the head of BP2T as set in the decree No. 52 of 2015 on mechanisms and procedures for licensing services and non-permissions on integrated licensing service agency district of Bone, Thus, the system is often called the service system "which begins and ends in BP2T". The highest authority in BP2T structure that are in the head of the agency, then the authority of level two, or directly at the operational level is the section head or the head of administration of sub-section. Thus the accountability relationship flows from the lower level to the head unit until the head of the agency.

Based on observations in BP2T, the authority of the head of the unit is very limited, there is no delegation of authority of the supreme leader issuing of licenses related to section heads, even if the head of the institution is absent for a long time. This suggests that the mechanism of the delegation of authority related to the licensing service in PTSP very formal, the delegation of authority is intended to speed up the process in the form of decentralization of authority, but in fact, the opposite is true and more centralized.

\subsection{Human Resources}

Good public service organizations must have qualified of human resources personnel in accordance with the needs of the organization. In addition, the availability of human resources must be balanced with the volume of work that is a burden on 
the organization. Based on the results on Integrated Licensing Service Agency in Bone regency show the number of employees in this office was still less than the volume of work as a PTSP has a wide working area as the district of Bone. It was a constraint on BP2T has a number of employees was not in accordance with the needs, so as to solve the problem, they used temporary employees or non-employee status of civil servants which are called the Non-Permanent Employee (PTT). The interpretation of the results of the observation shows that this institution is not correct to claim it as short-staffed because many of their temporary employees, but more precise was a qualified employee who is not in accordance with the organization requirement. These conditions will certainly have an impact on overall organizational performance.

The results of observation also showed that the discipline and responsibilities of employees of BP2T were still relatively low, in which the counter clerk often leave the premises during office hours, especially when visitors deserted. In addition, the observations of the employees' behavior while serving the users who need the service shows a lack of attention, they are often doing other things while dealing with the applicant, for example, communicating via a personal phone or talking with a colleague about things beyond duty, this shows the low attention of employees against applicants or residents of the community being served.

From the results of the exposure of the capacity development through technical training, it can be concluded that the intensity of the development of the capacity of BP2T's employees through technical training was still low with an average execution only once in a year and the quantity that follows the training was in an average of 1 in an every training. It was inseparable from the tasks and functions within BP2T that many technical natures that did not allow for other personnel from one area to represent other persons' fields. Their connection with the assignment of duties causes are areas of particular techniques that get a portion of the assignment more compared with other fields, this fact caused less inequality in knowledge and skills between local government apparatus.

\subsection{Systems and procedures}

Based on observations found that the licensing process was generally completed over a period of time determined in accordance with the standard operating procedures (SOP), there was the involvement of middlemen in the licensing service at BP2T who helps manage the users' licensing service by providing additional cost. The relationship between brokers and apparatus of BP2T as a partner has already well established. It is often becoming the spotlight and sometimes it cause jealousy for other citizens who take care of themselves without any intermediary. This indicates the phenomenon or the possibility of discrimination in service.

Based on interviews with informants from the apparatus BP2T found that procedurally it is not allowed to provide different services, but in fact, it still occurs in accordance with the recognition informants from the community. One of the factors that caused it to happen is the existence of a relationship and the closeness of the kinship system, so as to applicants who came alone and did not have any friends on BP2T, and then surely they would take formal procedures through various stages. Through all stages of the process that would require a short time due to a stall and personnel that must be passed. In addition, the management is not as easy as that to get through the stages of the process, because there are no barriers in terms of completeness and readiness of personnel files in serving. In such circumstances, the brokers played their role to anticipate many of these obstacles by helping the users.

The insensitivity of the apparatus and the weakness of their conscience in conducting the service made the difference to the applicants. It was demonstrated clearly that the authorities have not provided the treatment and decent appreciation to all applicants as individuals whose rights must be respected. The ability to interact with the apparatus in a different applicant was still influenced by the remuneration and mutual understanding. In this case, for applicants who were not expected to contribute to the apparatus, as expected, it may be difficult for them to approach personally to the authorities that his business can be processed smoothly. In contrast, for the applicant, or who was accustomed to taking care of through brokers will have easier access to services through a personal approach to the apparatus, especially the officers who were directly related to the service provider.

\section{Discussion}

Based on identification of bureaucratic reforms with a view of institutional, human resources, as well as systems and procedures in BP2T at Bone regency, then the implementation of bureaucratic reforms did not stand alone because it was a series of a cause and effect, so that, in realizing the reform of the bureaucracy needed an approach that is comprehensive and systemic as stated by Dugget (in Rewansyah, 2012) that the reform of the bureaucracy is a continuous process undertaken to redesign the bureaucracy who are in the government. From the results of this study found that the administrative services licensing of several complaints informants most prominent was the long period of 
time in obtaining a license. This inconsistency gave the difficulty for citizens to users of the service, so it was a deficiency that can be exploited by service providers and recipients of services to pursue a manner against the rules.

The study's findings of the apparatuses' customs to accept the incentives will cause them to commit acts of discrimination against service users. Base on the interviews with informants indicated that the use of intermediaries with incentives will make easier for users to achieve what they want but on the other hand, it would harm fellow community service users who are not using intermediaries. This is similar to the statement of Sumartono, et al (2012) that the essence of public service refers to the incentives are the decisive factor for the bureaucracy subordinates (street level bureaucracy) in the creation of service satisfaction to customers.

Based on these findings, many factors can become a bottleneck in the implementation of bureaucratic reform and against the principles of impersonality as developed by Weber. That principle has the purpose of encouraging the bureaucrats to act fairly and to be non-participant in providing services to the public. While this principle will also lead to a double effect (Dwiyanto, 2012), on the one hand, with the adoption of impersonality made the relationship between the bureaucrats and the public as users of services become the bureaucracy more straightforward and act objectively. But on the other hand, when the application of this principle becomes excessive, the bureaucratic apparatus can be a robot that did not have a sense of human being. Bureaucracy will also lose the chance to become the instrument of accession of partiality towards marginalized groups without the help of the bureaucracy cannot earn a decent living and useful.

The emergence of a few things on the quality of licensing services, both in terms of inaction in granting licenses has indicated that the organizer for the service of administrative licensing experiencing some problems, so that the necessary reforms in all aspects was crucial, both aspects of the increase in the number of employees to adapt to the volume of work, as well as aspects the change of bureaucratic mindset which referred to as "return to nature".

\subsection{Implications of the study}

In the context of theoretical, Fred W. Riggs explained transitional society called Prismatic Society (Prismatic). Transitional society is a society that is or is being moved from an agrarian society to an industrial society. The nature of developing country communities are the basic lack of neutrality of the bureaucracy, in general, people in these countries is a transitional society, among people who have traditional characteristics at once modern. Fred W. Riggs put the transitional phase as a prismatic society that when the pull linear line lies between a so-called fused traditional model of society as a society and diffracted society to a modern society. Traditional societies (fused society) called by the Chamber, while the advanced or modern society called the Office. As a community situated between both of them, the bureaucracy is called "Sala Model" or Bureau. This is called by prismatic society. Thus, the community is commonly known as the prismatic society (community prismatic).

In this article, the researcher applied a new term to see the connection to the phenomenon of bureaucracy in Indonesia, particularly in the service of licensing administration on BP2T Bone regency. The phenomenon in this study is called by the term "heresy regulation". The term "heresy" in the Great Dictionary of Indonesian (KBBI) can be interpreted deeds done not according to the pattern already established, while the use of the term "regulation" in KBBI interpreted as setting or rules.

In the context of this study, heresy regulation interpreted as a slogan that describes that in an organization there are some rules and procedures that have been defined, but it is not implemented properly and there are no strict sanctions, with a tolerance of violation that occurs naturally and has become a tradition that is used by a person or within the organization to achieve certain goals. Implications for the regulation of heresy seen by the high level of tolerance for violations even indicated cooperate with each other to gain an advantage.

Theoretically, the phenomenon was actually born as a result of formalization in excessive bureaucracy, so that interested parties trying to avoid formalization, though in a manner contrary to the rules. The principle of formalization in the bureaucracy is needed as a basis for decision-making as an official/bureaucratic official in providing the service to be fast and fair. It is very difficult for the bureaucrats gave the fast service and fair without clear procedures and rules. When bureaucratic officials to judge and decide for themselves without any procedures and rules that can facilitate and help each face the people who need the service, then the service will be very complicated bureaucratic burdensome and may vary between users of the service. The result will appear uncertainty services, so would be detrimental not only to end users but also the bureaucracy would lose image in the community.

In some of the interviews show that the phenomenon is an inhibitor of heresy regulatory reform of the bureaucracy has long attacked the government bureaucracy, including the bureaucracy of licensing services. As an institution that has the function of strategic and vital services, BP2T as PTSP agency has a set of rules and standards of care, but the implementation of the rules and standards of care have not been implemented optimally. 


\section{Conclusion}

This research is directed at identifying forms of bureaucratic reform in the public service, is one type of service that is shaped the PTSP licensing services to the Integrated Licensing Service Agency (BP2T) in Bone regency. Once identified forms of bureaucratic reforms, then analyzed to find how to reform the bureaucracy. As an outline of the conclusions of this study is that the institutional aspects, human resources, as well as systems and procedures have not proceed optimally.

Based on the results of previous studies, the majority of them focused on the internal factors of the bureaucracy to see in terms of institutions, structures, systems, and procedures. Based on the findings in this study one of the factors that also determine bureaucratic reform is the public as users of the service, where people voluntarily provide additional incentives to employees in the licensing. Basically, it is already forbidden for a predefined standard operating procedures of licensing, but because of the behavior of people who in theory Fired R Wigs of prismatic society where people who are in transition (modern and traditional).

Based on the findings, people in the district of bone is a transitional society (prismatic society) that sits between traditional and modern societies are basically aware of licensing rules standard payment but is paid, exceeds a predetermined standard. So that the community acts that influence bureaucratic reforms which in this paper is termed as "heresy regulation".

\section{References}

Azizuddin Muhammad. (2011). Administrative Reform in Bangladesh: An Overview of Political Dynamic. Inter Journal of public policy and Governance. Vol. xxviii No 1 June 2011 49-68.

Boniface .S. Mgonja \& Charles Tundui1. (2012). Institutional Impacts of the Local Government Reform Program on Good Local Governance in Tanzania . International Journal of Academic Research in Business \& Social. Vol.2.No.5. May. 2012.

Caiden,G.E, (1991). Administrative Reforms Comes of Age, New York, Walter de Gruyter.

Caiden, G.E., (1991). "What Really is Public Administration?" Public Admnistration Review, Vol.51, No. 6.

Carl Dahlström dkk. (2011). Dimensions of bureaucracy II: A cross national dataset on the structure and behavior of public administration. The QOG Institute Quality of Government. July. 2011.

Denhardt Robert B. dan Denhardt Janet V. (2006). Public Administration: An Action Overview, Fifth Edition. Thomson Wadsworth, United States of America. , (2003). The New Public Service Serving, not Steering, M.E. Sharpe, Armonk New York, London England.

Dwiyanto Agus, dkk. (2003). Reformasi Tata Pemerintahan dan Otonomi Daerah, Yogyakarta: Pusat Studi Kependudukan dan Kebijakan. Universitas Gajah Mada.

--, (2006). Reformasi Birokrasi Publik di Indonesia, Seri Kajian Birokrasi: Yogyakarta: Gajah Mada University Press.

Dwiyanto Agus (editor), (2006). Mewujudkan Good Governance Melalui Pelayanan Publik, Yogyakarta: Gajah Mada University Press.

-----------, (2010). Manajemen Pelayanan Publik: Peduli, Inklusif, dan Kolaboratif. Yogyakarta: Gadjah Mada University Press.

--, (2012). Mengembalikan Kepercayaan Publik Melalui Reformasi Birokrasi. Jakarta:Gramedia Pustaka Utama.

Frederickson, George H., (terjmh), (1987). Administrasi Negara Baru. Jakarta: LP3ES.

Frederickson, George H., (1977). Spirit of Public Administration. Jossey Bas Public Administration Series. Alabama.

Frederickson, George, H., dan Kevin B. Smith, (2003). The Public Administration Theory Primer. Westview Press.

Miles, Mathew B., dan Huberman, A. Michael, (2015). Analisisi Data Kualitatif: Buku Sumber Tentang Metode-Metode Baru. Penerjemah: Tjetjep Rohendi Rohidi, Jakarta: University Press.

Osborne, D. and Gaebler, T. (1993). Reinventing Governent: How the Enterpreneurial Spirit is Transforming the Public Sektor New York: Plume.

Osborne, D. and Plastrik, P., (1997). Banishing Bureaucracy: The Five Strategies for Reiventing Government. Addison-Wesley, reading, MA. Riggs, Fred W., (ed) (1994). Administrasi Pembangunan: Sistem Administrasi dan Birokrasi, Rajawali Press, Jakarta. . (1998). Administrasi Negara-negara Berkembang: Teori Masyarakat Prismatis, Rajawali Press, Jakarta.

Rewansyah Asmawi. (2012). Reformasi Birokrasi dalam rangka Good Governance. PT. Rizky Grafis. Jakarta.

Rosemary Anazodo, Joseph Okoye and Emma Chukwuemeke. (2012). Civil service in Nigeria: The journey so far in service delivery. American journal of social and management sciences. Pp.17-29. Accessed on 27 July 2015.

Sumartono. Sinambella, Poltak, Lijan. (2012). Reformasi Pelayanan Publik: Teori, Kebijakan dan Implementasi. Jakarta: PT. Bumi Aksara. 2007. Reformasi Administrasi dalam Pelayanan Publik. Pidato Pengukuhan Jabatan Guru Besar dalam IImu Reformasi Administrasi Negara pada Fakultas IImu Administrasi Universitas Brawijaya.

Sorin \& Sandor. (2012). ICT and Public Administration Reform. Rumania. Inter. Journal administarive Sciences. No. 36E/2012, pp.155-164.

Wijaya, Andy F dan Danar Oscar R. 2014. Manajemen Publik, Teori dan Praktek.UB.Press. Elektronik Pertama dan Terbesar di Indonesia. Malang. 